\title{
Early Period Evaluations after Varicocelectomy: Semen Analysis and Spontaneous Pregnancy Rates
}

\section{Varikoselektomi Sonrası Erken Dönemde Sperm Parametrelerinin ve Spontan Gebelik Oranlarının Değerlendirilmesi}

\author{
(D) Hasan Turgut ${ }^{1}, 2$ \\ ${ }^{1}$ Avrasya University Faculty of Healthy Science, Department of Nutrition and Dietetics, Trabzon, Turkiye \\ 2Medicalpark Karadeniz Hospital, Clinic of Urology, Trabzon, Turkiye
}

\section{What's known on the subject? and What does the study add?}

Patients should wait at least 6 months after varicocele surgery and should not immediately apply to assisted reproductive techniques as the spontaneous pregnancy rates will increase with improvement in sperm parameters. Thus avoiding both economic cost and a possible invasive intervention.

\begin{abstract}
Objective: The objective of this study is to evaluate and compare the sperm parameters and spontaneous pregnancy rates of patients with varicocele and primary infertility at three and six months after surgery.

Materials and Methods: We retrospectively evaluated the sperm parameters of 134 male patients who presented with clinical varicocele and primary infertility between July 2016 and May 2019. All the patients underwent microscopic inguinal varicocelectomy. We compared the sperm parameters (count, movement, and morphology) and spontaneous pregnancy of the patients preoperatively, and at three and six months postoperatively.

Results: In total, 134 patients with a mean age of 26.2 (20-38) years underwent the surgery. We found an increase in all the sperm parameters in the third and sixth months postoperatively. We also examined the differences among the sperm parameters in the third month and sixth month, and found a significant increase in the sperm count and motility at six months $(p<0.001)$. The postoperative third-month pregnancy rates were $2.9 \%$ $(\mathrm{n}=4)$ and $26.8 \%(\mathrm{n}=36)$ in the sixth month.

Conclusion: The improvement in sperm parameters in the third month after varicocele operation continued and increased by the postoperative sixth month. Therefore, patients with varicocele and primary infertility should be aware that the rate of spontaneous pregnancy could increase within six months and should wait for at least that period before applying for assistive reproductive techniques.
\end{abstract}

Keywords: Microscopic subinguinal varicocelectomy, Spermiogram, Varicocele

$0 \ddot{z}$

Amaç: Primer infertilitesi ve klinik varikoseli olan hastalarda varikoselektomi sonrası 3. ve 6. aylarda sperm parametrelerini karşılaştırdık ve spontan gebelik oranlarını değerlendirdik

Gereç ve Yöntem: Haziran 2016 - Mayıs 2019 tarihleri arasında üroloji polikliniğine gelen primer infertilitesi ve klinik varikoseli olan toplam 134 hastayı retrospektif olarak değerlendirdik. Tüm hastalara mikroskobik subinguinal varikoselektomi yapıldıktan sonra sperm parametreleri (sayı, hareket, morfoloji) ve spontan gebelik oranları preoperatif dönem ve postoperatif 3. ve 6. aylar değerlendirildi ve karşılaştırıldı.

Bulgular: Yüz otuz dört hastaya varikoselektomi yapıldı ve yaş ortalaması 26,2 (20-38) idi. Tüm sperm parametreleri 3. ve 6. ayda yükselmişti. Postoperatif 3. ve 6. ay karşılaştırıldığında sperm sayı ve hızında anlamlı derecede yükselme mevcuttu ( $<<0,001)$. Postoperatif 3 . ay gebelik oranı $\% 2,9(n=4)$ iken postoperatif 6 . ayda bu oran \%26,8 $(n=36)$ idi.

Sonuç: Varikoselektomi sonrası 3. ayda düzelen ve artış gösteren sperm parametreleri 6. ayda da yükselmeye devam etti. Primer enfertilite ile birlikte

Correspondence: Hasan Turgut MD, Avrasya University Faculty of Healthy Science, Department of Nutrition and Dietetics, Trabzon, Turkiye; Medicalpark Karadeniz Hospital, Clinic of Urology, Trabzon, Turkiye

E-mail: drhasanturgut@hotmail.com ORCID-ID: orcid.org/0000-0001-9793-6734

Received: 23.01.2020 Accepted: 19.02 .2020

Cite this article as: Turgut H. Early Period Evaluations after Varicocelectomy: Semen Analysis and Spontaneous Pregnancy Rates. J Urol Surg 2020;7(3):195199.

๑Copyright 2020 by the Association of Urological Surgery / Journal of Urological Surgery published by Galenos Publishing House. 
klinik varikoseli olan hastaların yardımcı üreme tekniklerine başvurmadan önce en azından 6 ay sonra sperm parametrelerindeki yükselmeye bağlı olarak yüksek oranda spontan gebelik intimali mevcuttur.

Anahtar Kelimeler: Mikroskopik subinguinal varikoselektomi, Spermiyogram, Varikosel

\section{Introduction}

Varicocele is a disease that causes the abnormal dilatation of testicular veins and, consequently, impaired spermatogenesis and infertility. It is also known to be the most common correctable cause of male infertility. Varicocele is found in up to $15 \%$ of the adult male population and occurs in $35 \%$ of men with primary infertility. Animal and human studies have demonstrated that varicocele is associated with a progressive and time-dependent decline in the testicular function. Further damage to the testes can be prevented by varicocele repair, and it will result in a positive outcome of spermatogenesis and increased leydig cell function in a large percentage of men (1). Microsurgical varicocelectomy is the gold standard of surgical treatment for clinical varicocele.

Although sperm parameters have been shown to improve after varicocelectomy, many fertility specialists want to learn the time which is best for improving the semen parameters after surgery (2). Few studies have shown an increase in sperm parameters, especially in patients with severe oligospermia after varicocele surgery (3). Spontaneous pregnancies are observed in patients with varicocele after surgery due to an increase in the sperm parameters. Nevertheless, no exact time has been defined for the maximal sperm parameters after varicocelectomy. The objective of this study is to compare the sperm parameters of patients with primary infertility and varicocele, preoperatively, and at the third and sixth months, postoperatively. This study further aims to determine the spontaneous pregnancy rates at these times.

\section{Materials and Methods}

We retrospectively evaluated 134 patients with clinic varicocele who underwent microscopic subinguinal varicocelectomy at our hospital from July 2016 to May 2019. All the patients were infertile couples who had presented at our hospital for urological evaluation including physical examination, semen analysis, and detailed anamnesis. The couples included in the study were those who had not achieved pregnancy despite regular sexual intercourse for at least one year. The obstetrics and gynaecology department evaluated all the female partners. and we excluded all the female causes of infertility. The parameters studied in the males included semen volume, number, motility, and morphology of sperm, preoperatively, and at three and six months postoperatively. The presence of varicocele was diagnosed by a physical examination in a temperature-controlled room at over $23^{\circ} \mathrm{C}$ under adequate illumination. Scrotal doppler ultrasound was performed on all the patients to exclude other testicular pathologies (such as tumor, epididymitis). In all the patients, preoperative semen analysis was performed by using two different semen specimens, each obtained by masturbation at least three weeks preoperatively and three and six months after varicocele treatment according to the recommendations of World Health Organization (2010). The duration of sexual abstinence was three to four days in all the patients. The interval between the two sample collections had to be more than seven days and less than three weeks. Semen analysis was performed manually and included the measurement of the volume of ejaculation and determination of sperm concentration, motility, and morphology according to the criteria of World Health Organization (4). We excluded the patients aged more than 40 years, were smokers, having or had hereditary disorders, genetic abnormalities such as Klinefelter syndrome or Y-chromosome microdeletion, primary hormonal disorders, ongoing use of medication that may affect fertility, subclinical varicocele, recurrent varicocele, complications of testicular atrophy, a history of testicular tumor and chemotherapy-radiotherapy, or azoospermia (obstructive or non-obstructive).

\section{Surgical Technique}

Subinguinal microsurgical varicocelectomy was performed under general anesthesia with a subinguinal incision of approximately $2-3 \mathrm{~cm}$. First, the spermatic cord was suspended and dissected under microscopic magnification (Leica Microsystems ${ }^{\odot}$ ). Next, the spermatic fascia was incised. Thereafter, the testicular artery and vas were safeguarded. All the internal spermatic veins were ligated. Importantly, testicular lymphatics and the vasal vein were preserved. The testis was delivered, and the external spermatic perforators were ligated. Then, gubernaculum veins were transfixed. Finally, the testis was re-positioned into the scrotum before the closure of wound.

\section{Statistical Analysis}

To assess normal distribution, we analyzed all the continuous variables via the Kolmogorov-Smirnov test and histogram. We used the Wilcoxon-Rank test to compare the variables. Importantly, we statistically analyzed the data obtained in the study by using SPSS for Windows version 22.0. 


\section{Results}

This study included 134 adult patients with clinical varicocele. The mean age of the patients was 26.2 years (range: $20-38$ years). No patient had any systemic disease or a history of testicular surgery. The preoperative physical examination revealed grade 1 , grade 2, and grade 3 varicocele diagnosed in 14 (10.4\%), 18 (13.4\%), and 102 (76.1\%) patients, respectively. Unilateral varicocele was determined in 110 (82\%) patients, whereas bilateral varicocele was determined in 24 (18\%) patients (Table 1). All the patients underwent microscopic subinguinal varicocelectomy operation under general anesthesia. The mean surgery time was 26.14 mins (range: 21-40 mins). None of the patients had perioperative or postoperative complications related to general anesthesia. Hydrocele not requiring surgical intervention was determined in 12 patients, epididymitisorchitis was resolved with antibiotic therapy in 6 patients, and an allergic reaction to the skin suture was determined in one patient, which was corrected by removing the suture (Table 2). Semen volume, number, fast forward motion (A), and slow forward motion (B) values were compared, preoperatively, and at three and six months postoperatively. A statistically significant increase was observed in all the sperm parameters in the postoperative third and sixth months as compared to the preoperative period $(p<0.001)$. The number of sperm and sperm movements $A$ and $B$ were statistically higher in the sixth month as compared to the postoperative third month $(p<0.001)$. There was no statistically significant difference between the semen volume and morphology ( $p>0.05$ ) (Table 3). Spontaneous pregnancy was observed in 4 couples (2.9\%) in the first 3 months and in 32 couples $(23.8 \%)$ between the $3^{\text {rd }}$ and $6^{\text {th }}$ months. Thus, spontaneous pregnancy was observed in 36 couples at the rate of $26.8 \%$ in the first 6 months.

\begin{tabular}{|l|l|l|l|}
\hline \multicolumn{4}{|l|}{ Table 1. Varicocele data of study population } \\
\hline Varicocele & $\begin{array}{l}\text { patients } \\
(\mathbf{n}=134)\end{array}$ & $\%$ \\
\hline \multirow{2}{|l|}{ Varicocele grade } & Grade 1 & 14 & 10.4 \\
\cline { 2 - 4 } & Grade 2 & 18 & 13.4 \\
\cline { 2 - 4 } & Grade 3 & 102 & 76.1 \\
\hline Varicocele side & Unilateral & 110 & 82 \\
\cline { 2 - 4 } & Bilateral & 24 & 18 \\
\hline
\end{tabular}

\begin{tabular}{|l|l|}
\hline \multicolumn{2}{|l|}{ Table 2. Complications } \\
\hline Complications & Patients (n) \\
\hline Hydrocele & 12 \\
\hline Epididymitis-orchitis & 6 \\
\hline Allergenic reaction & 1 \\
\hline
\end{tabular}

\section{Discussion}

The aim of this study is to determine the spontaneous pregnancy rate and difference in the sperm parameters in the third and sixth months after surgery in patients with varicocele and primary infertility, who wanted to have children. Varicocele, which is the most common cause of correctable male infertility, is detected in high rates among infertile couples. Patients believe that the results of treatment will be long-lasting and they may also want assisted reproductive techniques. Varicocelectomy is highly cost-effective, but it would be better for the patients to wait for six months before applying for assisted reproductive techniques. The results of this study showed that surgery was effective both in the third and sixth months postoperatively in increasing both the sperm parameters and the spontaneous pregnancy rate in patients with primary infertility and varicocele.

Few studies have shown the time when spermatogenesis improves after varicocelectomy. Al Bakri et al. (2) published a study showing recovery at up to three months in men with oligospermia. However, there was no increase in the sperm parameters in the follow-up after six months (2). Another study by Enatsu et al. (5) showed a positive increase in the sperm count and motility in patients with varicocele and oligospermia with a mean follow-up of 8.2 months. Thomas et al. (3) evaluated patients with severe oligospermia between the third and sixth months after surgery and after six months. They found that the sperm count increased in both the groups (different periods) as compared to the preoperative period, but there was no difference in the sperm quality between three and six months and after six months (3). Postoperative improvements in the sperm parameters have been observed in 95\% of cases (6); however, most studies have shown varicocele to have negative effects on spermiogram (7-9).

Our study observed a significant positive difference in the sperm count, motility, and morphology in the postoperative third and sixth months as compared to the preoperative period.

Reports on varicocele and infertility issued by the Practice Committee of the American Society for Reproductive Medicine and the American Urological Association's Male Infertility Best Practice Policy Committee suggest that for couples dealing with infertility in which if there is no proof (or potential cause) of infertility in a woman, the correction of abnormal sperm parameters in the males with varicocele may be considered $(10,11)$. However, the guidelines of the European Association of Urology on male infertility found varicocele treatment for pregnancy to be controversial (12). The National Institute for Health and Clinical Excellence clinical guideline on fertility does not recommend varicocele surgery for men in the treatment of infertility because it does not increase the pregnancy rates (13). 
Table 3. The comparison of pre and postoperative results of sperm analysis

\begin{tabular}{|l|l|l|l|l|l|l|}
\hline & Preoperative & $\begin{array}{l}\text { Postoperative } \\
\text { third month }\end{array}$ & $\begin{array}{l}\text { Postoperative } \\
\text { sixth month }\end{array}$ & $\mathbf{p}^{1}$ & $\mathbf{p}^{2}$ & $\mathbf{p}^{3}$ \\
\hline Semen volume $(\mathrm{mL})$ & $2.32 \pm 0.5$ & $2.35 \pm 0.4$ & $2.39 \pm 0.45$ & 0.6 & 0.25 & 0.48 \\
\hline Sperm number (million/mL) & $13 \pm 6.4$ & $17.7 \pm 8.4$ & $27.8 \pm 7.8$ & $<0.001$ & $<0.001$ & $<0.001$ \\
\hline A fast forward & $0.9 \pm 1$ & $3 \pm 1.4$ & $9.9 \pm 3.1$ & $<0.001$ & $<0.001$ & $<0.001$ \\
\hline B slow forward & $10.5 \pm 7.2$ & $20.4 \pm 4.9$ & $23.1 \pm 3.5$ & $<0.001$ & $<0.001$ & $<0.001$ \\
\hline Sperm morphology & $1.1 \pm 0.9$ & $4.5 \pm 1.1$ & $4.6 \pm 1.2$ & $<0.001$ & $<01$ \\
\hline$p^{1}$ : Preoperative vs postoperative third month, $p^{2}$ : Preoperative vs postoperative sixth month, $p^{3}$ : Postoperative third month vs postoperative sixth month \\
\hline
\end{tabular}

Early studies showed that sperm parameters and pregnancy rates increased after varicocelectomy. Schlesinger et al. (14) reported that the semen quality increased in 70\%, especially sperm density, and spontaneous pregnancy rates increased from $30 \%$ to $60 \%$. In a study conducted by Marmar and Kim (15), 186 male patients who underwent varicocele surgery had a one-year spontaneous pregnancy rate of 36\%, whereas the pregnancy rates of 19 patients with varicocele receiving medical treatment was 16\%. In another study conducted by Madgar et al. (16), 25 patients who underwent varicocelectomy had a oneyear pregnancy rate of $60 \%$, whereas 20 male patients treated conservatively had a pregnancy rate of 10\%. Marmar et al. (17) reviewed five studies with two randomized controlled trials and three observational studies, and selected infertile men with palpable varicoceles and abnormal sperm parameters. The odds of spontaneous pregnancy after varicocelectomy as opposed to conservative management were 2.6-2.9. That study suggested that varicocelectomy had beneficial effects on fertility in the selected patients (17). None of those studies investigated the third- and sixth-month pregnancy rates. This study found an increase in all the sperm parameters and pregnancy rates in the third and sixth months. The spontaneous conception rate was 2.9\% (four patients) in the first third months, and 23.8\% (32 patients) between the third and sixth months. The total pregnancy rate in the first six months was 26.8\% (36 patients).

Spontaneous pregnancy rates increased in the third and sixth months due to the increase in the sperm parameters. Although there was a difference in the sperm count and sperm slow motion between the two periods, the difference between the fast-forward sperm movement increased significantly in the 6th month (Figure 1).

Varicocelectomy has been shown to be a more advantageous procedure than assisted reproductive techniques in terms of cost-effectiveness. Penson et al. (18) reported that intrauterine insemination (IUI) costs $\$ 50,000$ more than varicocelectomy per additional live birth. Considering the positive changes observed in the sperm parameters after varicocele surgery, its contribution to the national economy should not be ignored. Our study observed high rates of spontaneous pregnancy even in the first 6 months in couples who wanted to have children.

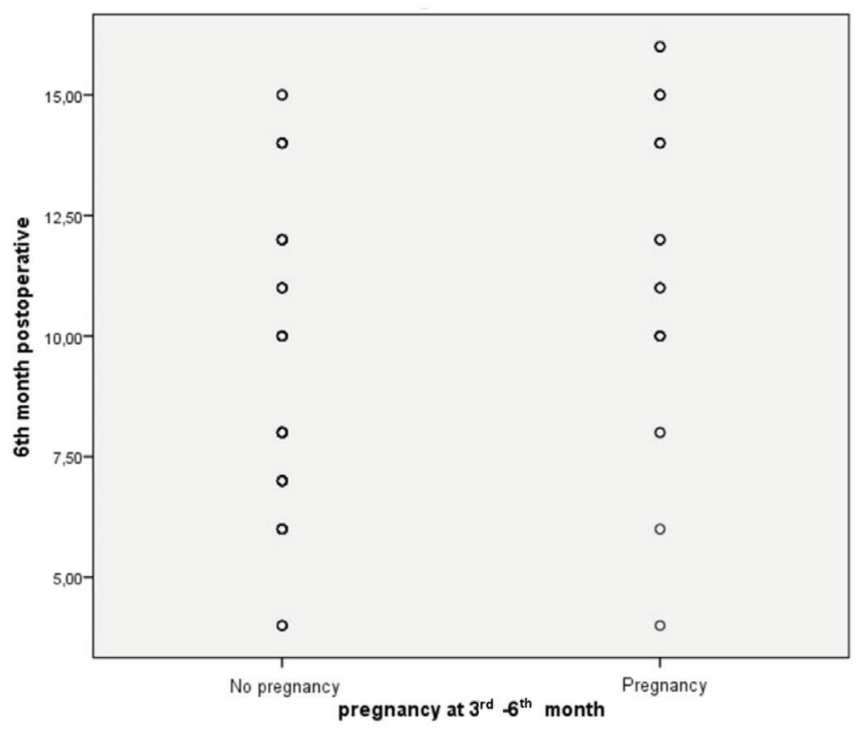

Figure 1. Determination of spontaneous pregnancy rates with fast-forward sperm motions between third month and third-sixth months

Therefore, the surgical correction of varicocele before assisted reproductive techniques would be economically beneficial.

Many patients with varicocele may still require assisted reproductive techniques for pregnancy. As the sperm parameters will improve after varicocele surgery, the ejaculate sample to be used in IUI will be of better quality and the results will be better. If IUI fails, then intrastoplasmic injection as an alternative treatment will increase the chances of success and avoid the invasive procedures [such as micro-testicular sperm extraction (TESE)]. Some studies have shown that the use of ejaculated sperm is technically easier and provides better results than the sperm harvested from TESE $(15,19)$. Additionally, it avoids the risk of ICSI cycle cancellation by an unsuccessful TESE or the use of donor backup (20).

\section{Study Limitations}

The primary limitations of this study are the small sample size and retrospective design. In addition, it was not possible to obtain full information about the lifestyle of patients (medical treatment for infertility, smoking, sports, etc) either pre- or postoperatively. Therefore, there was no evaluation of any positive or negative effects of lifestyle changes on 
sperm parameters. More studies should also be conducted for evaluating the effects of varicocelectomy to pregnancy after a long period. Furthermore, the age and fertility history of the female partner was not considered.

\section{Conclusions}

The observations of this study suggest an increase in the sperm count, morphology, and motility after microscopic subinguinal varicocelectomy in patients with clinical varicocele. These changes were observed in the spermiogram performed in the third month after surgery, but more positive results can be obtained in the spermiogram in the sixth month. For these patients to obtain a spontaneous pregnancy, waiting for at least six months for assisted reproductive techniques would be more effective.

\section{Ethics}

Ethics Committee Approval: It was received for this study from the ethics committee of Trabzon Karadeniz Medicalpark Hospital (no: 229/2020).

Informed Consent: Written informed consent was obtained from the all patients before the surgery.

Peer-review: Externally and internally peer-reviewed.

Financial Disclosure: The authors declared that this study received no financial support.

\section{References}

1. Wein AJ, Kavoussi LR, Partin Alan W. Campbell-Walsh, 11th ed. 2016, Elsevier Saunders, 2016

2. Al Bakri A, Lo K, Grober E, Cassidy D, Cordoso JP, Jarvi K. Time for improvement in semen parameters after varicocelectomy. J Urol 2012;187:227-231.

3. Thomas $A M$, Greer $A B$, Ramasamy R. Time to improvement in semen parameters after microsurgical varicocelectomy in men with severe oligospermia. Can Urol Assoc J 2019;13:66-69.

4. World Health Organization, Laboratory Manual for the Examination of Human Semen and Sperm-CervicalMucus Interaction, Cambridge University Press, New York, NY, USA, 4th edition, 1999.
5. Enatsu N, Yamaguchi K, Chiba K. Clinical outcome of microsurgical varicocelectomy in infertil men with severe oligospermia. Urology 2014;83:1071-1075

6. Tellaloğlu S, Kadıŏlu TC, Çayan S. Microsurgical high inguinal varicocelectomy and high ligation compared in tratment of varicocele. $\mathrm{Br} J$ Urol 1997;80:108.

7. Johnsen SG, Agger P. Quantitative evaluation of testicular biopsies before and after operation for varicocele. Fertil Steril 1978;29:58.

8. Cockett AT, Harrison RM. Comhaire F, Dublin L. The varicocel and its effect on fertility. Contemp Surg 1984;24:111.

9. Saypol DC, Howards SS, Turner TT, Miller ED. Influence of surgically induced varicocele on testicular blood flow, temperature, and histology in adults rats and dogs. Clin Invest 1981;68:39-45.

10. Male Infertility Best Practice Policy Committee of the American Urological Association; Practice Committee of the American Society for Reproductive Medicine. Report on varicocele and infertility. Fertil Steril 2004;82(Suppl 1):142-145.

11. Practice Committee of American Society for Reproductive Medicine. Report on varicocele and infertility. Fertil Steril 2008;90(Suppl 5):247-249.

12. Dohle GR, Colpi GM, Hargreave TB, Papp GK, Jungwirth A, WeidnerW. The EAU Working Group on Male Infertility. EAU guidelines on male infertility. Eur Urol 2005:48:703-711.

13. National Collaborating Centre for Women's and Children's Health (UK). Fertility: assessment and treatment for people with fertility problems: clinical guideline February 2004

14. Schlesinger MH, Wilets IF, Nagler HM. Treatment outcome after varicocelectomy. A critical analysis. Urol Clin North Am 1994;21:517-529.

15. Marmar JL, Kim Y. Subinguinal microsurgical varicocelectomy: a technica critique and statistical analysis of semen and pregnancy data. J Urol 1994;152:1127-1159.

16. Madgar I, Weissenberg R, Lunenfeld B, Karasik A,Goldwasser B. Controlled trial of high spermatic vein ligation for varicocele in infertile men. Fertil Steril 1995;63:120-124.

17. Marmar JL, Agarwal A, Prabakaran S, Agarwal R, Short RA, Benoff S, Thomas AJ Jr. Reassessing the value of varicocelectomy as a treatment for male subfertility with a new meta-analysis. Fertil Steril 2007;88:639-687.

18. Penson DF, Paltiel AD, Krumholz HM, Palter S. The costeffectiveness of treatment for varicocele related infertility. J Urol 2002;168:2490-2494.

19. Verza S Jr, Esteves SC. Sperm defect severity rather than sperm source is associated with lower fertilization rates after intracytoplasmic sperm injection. Fertil Steril 2004;82:17.

20. Aboulghar MA, Mansour RT, Serour Gl, Fahmy I, Kamal A, Tawab NA Amin YM. Fertilization and pregnancyrates after intracytoplasmic sperm injection using ejaculate semen and surgically retrieved sperm. Fertil Steril 1997:68:108-111. 